\title{
Control of endometrial oxytocin receptor and uterine response to oxytocin by progesterone and oestradiol in the ewe
}

\author{
J. L. Vallet, G. E. Lamming and M. Batten \\ AFRC Research Group on Hormones and Farm Animal Reproduction, University of Nottingham, \\ Sutton Bonington, Loughborough, Leics LE12 SRD, UK
}

\begin{abstract}
Summary. The effects of administration of progesterone and oestradiol on ovine endometrial oxytocin receptor concentrations and plasma concentrations of 13,14-dihydro15-keto prostaglandin F-2 $\alpha$ (PGFM) after oxytocin treatment were determined in ovariectomized ewes. Ewes received progestagen pre-treatment, progesterone and/or oestradiol in 11 different treatment schedules.

Progestagen pre-treatment decreased oxytocin receptor concentrations in endometrium from ewes treated subsequently with either progesterone for 5 days or progesterone for 5 days plus oestradiol on Days 4 and 5 of progesterone treatment. Oestradiol increased endometrial oxytocin receptor concentrations when administered on Days 4 and 5 of 5 days progesterone treatment. Progestagen pre-treatment followed by progesterone treatment for 12 days caused a large increase in oxytocin receptors and no further increase occurred when ewes were given oestradiol on Days 11 and 12, or when progesterone was withdrawn on Days 11 and 12, or these two treatments were combined.

Oxytocin administration caused an increase in plasma PGFM concentrations in ewes which did not receive progestagen pre-treatment, and subsequently received progesterone treatment for 5 days and oestradiol treatment on Days 4 and 5 of progesterone treatment. Similarly treated ewes which received progestagen pre-treatment did not respond to oxytocin. Oxytocin administration also increased plasma PGFM concentrations in ewes which received progestagen pre-treatment followed by progesterone treatment for 12 days, progesterone treatment for 12 days plus oestradiol on Day 11 and 12 of progesterone treatment, progesterone withdrawal on Day 11 and 12, or progesterone withdrawal and oestradiol treatment combined. The results indicate that (1) progesterone pre-treatment affects oxytocin receptor concentrations in the endometrium and uterine responsiveness to oxytocin and (2) progesterone treatment alone for 12 days after a treatment which mimics a previous luteal phase and oestrus is sufficient to induce oxytocin receptors and increase oxytocin-induced PGF release. These results emphasize the importance of progesterone and provide information which can be used to form an hypothesis for control of luteolysis and oestrous cycle length in the ewe.
\end{abstract}

Keywords: progesterone; oestradioi; oxytocin; receptor; 13,14-dihydro-15-keto PGF-2

\section{Introduction}

Prostaglandin (PG) F-2 $\alpha$ secreted by the uterus initiates luteolysis in the ewe (Goding, 1974). Oxytocin secreted by the corpus luteum has been proposed to control the release of uterine PGF (McCracken, 1980). Oxytocin receptor concentrations increase in the uterine endometrium at luteolysis (Roberts et al., 1976; Sheldrick \& Flint, 1985), oxytocin stimulates uterine secretion of PGF (Roberts et al., 1975), most pulses of PGF during luteolysis coincide with pulses of oxytocin in 
plasma (Flint \& Sheldrick, 1983; Hooper et al., 1987) and immunization of ewes against oxytocin extends the interoestrous interval (Sheldrick et al., 1980).

Both progesterone and oestrogen are also involved in controlling uterine production of PGF. Treating intact ewes with progesterone on Days $1-5$ of the oestrous cycle (Day $0=$ first day of oestrus) increases oestradiol-induced PGF concentrations in uterine venous plasma, and oestradiol alone induces PGF release in long-term ovariectomized ewes (Ford et al., 1975). Louis et al. (1977) reported that ewes treated with progesterone for 9 days had increased endometrial tissue PGF content and production in vitro and the additon of oestradiol further increased PGF content and PGF production. Scaramuzzi et al. (1977) reported that progesterone treatment for 7 or 14 days increased PGF release from the uterus after autotransplantation to the neck and oestradiol given after progesterone treatment for 14 days further increased PGF. These experiments suffer from two problems. First, superphysiological amounts of steroid hormones were sometimes used. Second, there is evidence that uterine function may be affected by progesterone pre-treatment. Pregnancy cannot be maintained in ovariectomized ewes unless ewes are pre-treated with progesterone and then oestrogen followed by progesterone (Miller et al., 1977). Also, McLeod et al. (1982) reported that normal luteal function could only be obtained from anoestrous ewes treated with GnRH every $2 \mathrm{~h}$ if they were first treated with progesterone. Southee et al. (1988a) found that the inadequate luteal function in GnRH-treated ewes was caused by premature luteal regression and Southee et al. (1988b) showed that normal luteal function could result in non-pretreated ewes if the uterus was removed, suggesting that in unprimed ewes premature release of uterine luteolysin occurs and causes the early regression of the corpus luteum. Finally, Hunter et al. (1989) reported that in anoestrous ewes induced to ovulate by giving GnRH, premature luteolysis occurs and is coincident with an increase both in uterine oxytocin receptor level and PGF release. Progesterone pre-treatment prevented the premature luteolysis and also decreased oxytocin receptors and $\mathrm{PGF}$ release. One possible explanation for these findings is that progesterone pre-treatment has a direct effect on endometrium to alter endometrial response to progesterone and oestrogen in the luteal phase of the next cycle.

An experiment which incorporated progesterone pre-treatment and also used physiological levels of steroid was recently reported (Homanics \& Silvia, 1988), and indicated that progesterone treatment for 15 days was sufficient to induce PGF release in response to oxytocin. Homanics \& Silvia (1988) did not indicate whether the increase in PGFM secretion in response to oxytocin was a result of increased oxytocin receptor concentration in endometrium. Also, they did not examine whether progesterone pre-treatment had an effect on subsequent uterine response to progesterone. Finally, they used a dose of oxytocin which is $10-20$ times higher than that which is thought to occur in vivo.

The present experiment was performed with the following objectives: (1) to determine whether the increase in uterine responsiveness to oxytocin in steroid hormone-treated ovariectomized ewes occurs coincident with an increase in oxytocin receptor concentrations in uterine endometrium and (2) to determine whether progestagen pre-treatment of ewes has an effect on subsequent responses to progesterone and oestrogen.

\section{Materials and Methods} Animals. Forty-four Finn-Dorset ewes were ovariectomized during seasonal anoestrum. One week later, ewes were
allocated at random to the 11 treatments described in Table 1 . Progestagen pre-treatment consisted of the insertion
and maintenance of a fluorogestone acetate-impregnated pessary (Chronogest, Intervet UK Ltd, Cambridge, UK)
intravaginally for 10 days. Oestradiol, when given, was administered intramuscularly at a dose of $25 \mu \mathrm{g}$ twice daily for
2 days in $0.5 \mathrm{ml}$ corn oil. Oestradiol treatment was given to mimic 'oestrus' oestradiol (i.e. after progestagen pre-
treatment or no pre-treatment) or to mimic 'follicular-wave' oestradiol (i.e. at the end of 5 , 10 or 12 days progesterone
treatment which mimicked the luteal phase). Progesterone, when given, was administered intramuscularly at a dose of
10 mg twice daily in $0.5 \mathrm{ml}$ corn oil. These doses of progesterone and oestradiol are similar to those which have been
reported to generate physiological concentrations of both progesterone and oestradiol in plasma (Louis et al., 1977).
The jugular vein of all ewes was cannulated $2-3$ days before the end of steroid treatment. On the morning after the last 
injection in the treatment schedule, all ewes received a bolus injection through the jugular cannula of $1 \mu \mathrm{g}$ oxytocin in $1 \mathrm{ml} 0.9 \%(\mathrm{w} / \mathrm{v}) \mathrm{NaCl}$ followed by $1 \mathrm{ml} 0.9 \%(\mathrm{w} / \mathrm{v}) \mathrm{NaCl}$ to clear the cannula. Blood samples $(5 \mathrm{ml})$ were collected just before and every $10 \mathrm{~min}$ for $\mathrm{l} \mathrm{h}$ after oxytocin administration. Ewes were then slaughtered within $2 \mathrm{~h}$ of the end of the blood sampling period and the uterus obtained. It has been shown previously that treatment of ewes with $1 \mu \mathrm{g}$ oxytocin does not affect subsequent oxytocin receptor measurement (Sheldrick \& Flint, 1986).

Table 1. Treatment schedule of ewes $(\mathrm{N}=4$ /group $)$ in the 11 treatments used to study the effects of oestradiol and progesterone on endometrial oxytocin receptor and PGF release

\begin{tabular}{lccccccc}
\hline Treatment ${ }^{\dagger}$ & $\begin{array}{c}\text { Day } 10^{*} \\
\text { to Day 0 }\end{array}$ & $\begin{array}{c}\text { Day 0 } \\
\text { Day 1 }\end{array}$ & $\begin{array}{c}\text { Day 2- } \\
\text { Day 4 }\end{array}$ & $\begin{array}{c}\text { Day 5- } \\
\text { Day 6 }\end{array}$ & $\begin{array}{c}\text { Day 7- } \\
\text { Day 11 }\end{array}$ & $\begin{array}{c}\text { Day 12- } \\
\text { Day 13 }\end{array}$ & Day 14 \\
\hline (1) $\mathrm{CO}$ & $\mathrm{NT}$ & $\mathrm{CO}$ & $\mathrm{CO}$ & $\mathrm{CO}$ & $\mathrm{S}$ & & \\
(2) $\mathrm{E}+\mathrm{CO}$ & $\mathrm{NT}$ & $\mathrm{E}$ & $\mathrm{CO}$ & $\mathrm{CO}$ & $\mathrm{S}$ & & \\
(3) $\mathrm{PP}+\mathrm{E}+\mathrm{CO}$ & $\mathrm{PP}$ & $\mathrm{E}$ & $\mathrm{CO}$ & $\mathrm{CO}$ & $\mathrm{S}$ & & \\
(4) $\mathrm{PP}+\mathrm{E}+5 \mathrm{P}$ & $\mathrm{PP}$ & $\mathrm{E}$ & $\mathrm{P}$ & $\mathrm{P}$ & $\mathrm{S}$ & & \\
(5) $\mathrm{PP}+\mathrm{E}+5 \mathrm{P}+4,5 \mathrm{E}$ & $\mathrm{PP}$ & $\mathrm{E}$ & $\mathrm{P}$ & $\mathrm{P}+\mathrm{E}$ & $\mathrm{S}$ & & \\
(6) $\mathrm{NP}+\mathrm{E}+5 \mathrm{P}$ & $\mathrm{NT}$ & $\mathrm{E}$ & $\mathrm{P}$ & $\mathrm{P}$ & $\mathrm{S}$ & & $\mathrm{S}$ \\
(7) $\mathrm{NP}+\mathrm{E}+5 \mathrm{P}+4,5 \mathrm{E}$ & $\mathrm{NT}$ & $\mathrm{E}$ & $\mathrm{P}$ & $\mathrm{P}+\mathrm{E}$ & $\mathrm{S}$ & $\mathrm{P}$ & $\mathrm{S}$ \\
(8) $\mathrm{PP}+\mathrm{E}+12 \mathrm{P}$ & $\mathrm{PP}$ & $\mathrm{E}$ & $\mathrm{P}$ & $\mathrm{P}$ & $\mathrm{P}$ & $\mathrm{P}+\mathrm{E}$ & $\mathrm{S}$ \\
(9) $\mathrm{PP}+\mathrm{E}+12 \mathrm{P}+11,12 \mathrm{E}$ & $\mathrm{PP}$ & $\mathrm{E}$ & $\mathrm{P}$ & $\mathrm{P}$ & $\mathrm{P}$ & $\mathrm{NT}$ & $\mathrm{S}$ \\
(10) PP $+\mathrm{E}+10 \mathrm{P}+11,12 \mathrm{NT}$ & $\mathrm{PP}$ & $\mathrm{E}$ & $\mathrm{P}$ & $\mathrm{P}$ & $\mathrm{P}$ & $\mathrm{N}$ & $\mathrm{S}$ \\
(11) PP $+\mathrm{E}+10 \mathrm{P}+11,12 \mathrm{E}$ & $\mathrm{PP}$ & $\mathrm{E}$ & $\mathrm{P}$ & $\mathrm{P}$ & $\mathrm{P}$ & $\mathrm{E}$ & \\
\hline
\end{tabular}

*First day of insertion of fluorogestone acetate-impregnated pessary is Day -10 .

¥ Treatments were: no treatment (NT), corn oil (CO, $0.5 \mathrm{ml}$ twice daily), oestradiol (E, $25 \mu \mathrm{g}$ twice daily in $0.5 \mathrm{ml}$ corn oil), progestagen pre-treatment ( $\mathrm{PP}$, intravaginal insertion of fluorogestone-impregnated pessary) and progesterone (P, $10 \mathrm{mg}$ twice daily in $0.5 \mathrm{ml}$ corn oil) on the days indicated. Ewes were slaughtered (S) on the morning after the last day of treatment.

Endometrium was prepared for measurement of oxytocin receptor and oxytocin binding was determined as described by Sheldrick \& Flint (1985). [Tyrosyl-3,5- ${ }^{3} \mathrm{H}$ ]oxytocin (sp. act. $39 \cdot 3 \mathrm{Ci} / \mathrm{mmol}$ ) was purchased from New England Nuclear (Stevenage, Herts, UK). Protein concentrations of membrane fractions from endometrium of each ewe were determined using the method of Lowry et al. (1951) using bovine serum albumin (BSA) as standard. Each assay consisted of $50 \mu \mathrm{l}(\mathrm{l} \mathrm{mg}$ protein $/ \mathrm{ml})$ membranes in $25 \mathrm{~mm}$-Tris, $\mathrm{pH} 7.6 ; 25 \mu \mathrm{l} 0.6 \% \mathrm{BSA}, 6 \mathrm{mM}-\mathrm{MnCl}_{2}$ in Tris; $25 \mu \mathrm{l}$ labelled oxytocin $\left(2 \cdot 4,12\right.$ or $60 \mathrm{nM}-\left[{ }^{3} \mathrm{H}\right]$ oxytocin) in Tris and $50 \mu \mathrm{l} 25 \mathrm{~mm}$-Tris (total bound) or $50 \mu \mathrm{l} 25 \mathrm{~mm}$-Tris, $3 \mu \mathrm{M}$ unlabelled oxytocin (non-specific binding) in duplicate, giving a total volume of $150 \mu \mathrm{l}$. The assays were therefore carried out using $0 \cdot 1 \% \mathrm{BSA}, 1 \mathrm{~mm}-\mathrm{MnCl}_{2}, 50 \mu \mathrm{g}$ membrane protein, $0 \cdot 4,2$ or $10 \mathrm{nM}-\left[{ }^{3} \mathrm{H}\right]$ oxytocin with and without $1 \mu \mathrm{M}$ unlabelled oxytocin (used to measure total and non-specific binding). Tubes were incubated for $15 \mathrm{~min}$ at $25^{\circ} \mathrm{C}$. Bound oxytocin was separated from free oxytocin by filtration under vacuum using a manifold (GVWP, $0.22 \mu \mathrm{m}$ filters, Millipore Corp., Bedford, MA 01730, USA) and washing with $2 \mathrm{ml} 0 \cdot 1 \% \mathrm{BSA}, 1 \mathrm{~mm}-\mathrm{MnCl}_{2}$ in $25 \mathrm{~mm}$ Tris, $\mathrm{pH}$ 7.6. Filters were placed into scintillation vials $(20 \mathrm{ml})$ along with $1 \mathrm{ml}$ 2-ethoxyethanol and $10 \mathrm{ml}$ scintillation fluid (Packard 299, Pangbourne, Berks, UK) and radioactivity was determined by scintillation counting ( $5 \mathrm{~min}$ ) using a Packard Tri-Carb 1990 CA liquid scintillation counter (efficiency $15-20 \%$ ).

To obtain an estimate of receptor affinity and maximal binding, binding was determined in duplicate at three $\left[{ }^{3} \mathrm{H}\right]$ oxytocin concentrations $(0 \cdot 4,2$ and $10 \mathrm{nM}$-oxytocin). Scatchard analysis of the binding data was then performed to determine the affinity constant $\left(K_{\mathrm{A}}\right)$ and maximal binding $\left(R_{0}\right)$. Binding at $10 \mathrm{nM}$-oxytocin $\left(R_{10}\right)$ was also calculated to compare these results with results obtained using the method of Sheldrick \& Flint (1985). Non-specific binding at $10 \mathrm{nM}-\left[{ }^{3} \mathrm{H}\right]$ oxytocin was $0.59 \%$ of the total label used. Sensitivity of measurement of binding at $10 \mathrm{nM}-\left[{ }^{3} \mathrm{H}\right]$ oxytocin (calculated as two standard deviations greater than non-specific binding) was $31.6 \mathrm{fmol} / \mathrm{mg}$ protein. Coefficient of variation (intra-assay) of binding at $10 \mathrm{nM}-\left[{ }^{3} \mathrm{H}\right]$ oxytocin was $9 \cdot 7 \%$ (excluding samples below sensitivity). Binding of oxytocin at a concentration of $10 \mathrm{nM}-\left[{ }^{3} \mathrm{H}\right]$ oxytocin for endometrial membranes prepared from ewes from Day 15 $(n=4)$ and Day $1(n=3)$ of the cycle were 883.8 (range 326-1930 fmol $/ \mathrm{mg})$ and 1953.9 (range $1061-2864 \mathrm{fmol} / \mathrm{mg}$ ) protein, respectively. These results are higher than those reported by Sheldrick \& Flint (1985) but are still within the range quoted by these authors, who have found receptor concentrations as high as $3000 \mathrm{fmol} / \mathrm{mg}$ protein for oestrous ewes (E. L. Sheldrick, personal communication). To determine the usefulness of Scatchard analysis at the three oxytocin concentrations described above, oxytocin binding to endometrial membranes was evaluated using membranes collected from ewes from Day 1 (Day $0=$ day of oestrus) of the cycle. Receptor $K_{\mathrm{A}}$, dissociation constant $\left(K_{\mathrm{D}}\right)$ and $R_{\mathrm{o}}$ were determined using $6\left[{ }^{3} \mathrm{H}\right]$ oxytocin concentrations $\left(0 \cdot 4,1,2,4,7.5\right.$ and $10 \mathrm{nM}-\left[{ }^{3} \mathrm{H}\right]$ oxytocin) and then compared with results obtained using three concentrations. The $K_{\mathrm{A}}, K_{\mathrm{D}}$ and $R_{\mathrm{o}}$ values obtained using the 6 concentrations were $0.2632 \times 10^{9} \mathrm{M}^{-1}, 4.174 \times 10^{-9} \mathrm{M}$ and $2919 \mathrm{fmol} / \mathrm{mg}$ protein, respectively, and those with 3 concentrations were $0.303 \times 10^{9} \mathrm{M}^{-1}, 3.43 \times 10^{-9} \mathrm{M}$ and $2695 \mathrm{fmol} / \mathrm{mg}$ protein, respectively. These represent differences of $15 \%, 18 \%$ and $7.6 \%$, respectively. We therefore felt justified in using results obtained with only three $\left[{ }^{3} \mathrm{H}\right]$ oxytocin concentrations. 
PGFM radioimmunoassay. All blood samples were centrifuged $(3000 \mathrm{~g})$ and the plasma was collected and frozen at $-20^{\circ} \mathrm{C}$ until assayed. Samples were assayed for PGFM using the method of Kaker et al. (1984). Inter- and intra-assay coefficients of variation were 26 and $8.6 \%$, respectively. Cross-reactivity of the antibody used was reported by Kaker et al. (1984). The working range of the assay was from 60 to $2000 \mathrm{pg} / \mathrm{ml}$. Extraction efficiency was approximately $83 \%$.

Statistical analysis. The $K_{\mathrm{A}}, R_{\mathrm{o}}$ and $R_{10}$ values were analysed by analysis of variance. Differences between treatment means were determined using the following mean comparisons: (1) Treatment 2 compared with Treatment $3 ;$; 2 ) Treatment 1 compared with Treatments 2 and 3 combined (effect of oestrus oestradiol); (3) Treatments 4 and 5 combined compared with Treatments 6 and 7 combined (effect of progestagen pre-treatment); (4) Treatments 4 and 6 combined compared with Treatments 5 and 7 (effect of 'follicular-wave' oestradiol after 5 days of progesterone); (5) Treatments 4 and 7 compared with Treatments 5 and 6 (interaction of progestagen pre-treatment and 'follicular-wave' oestradiol after 5 days of progesterone treatment); (6) Treatment 8 compared with Treatment 10 (effect of removal of progesterone); (7) Treatment 9 compared with Treatments 8 and 10 combined (effect of 'follicular-wave' oestradiol after 12 days' progesterone). The above comparisons are orthogonal. The following non-orthogonal comparisons were also made: (8) Treatments 4 and 5 combined compared with Treatments 8 and 9 combined ( 5 days progesterone treatment versus 12 days progesterone treatment); (9) Treatments 4 and 8 combined compared with Treatments 5 and 9 combined (effect of 'follicular-wave' oestradiol within progestagen pre-treated ewes); (10) Treatments 4 and 9 combined compared with Treatments 5 and 8 combined (interaction of number of days of progesterone treatment with 'follicular-wave' oestradiol treatment). Because the variance was greater in treatment groups 8-11, values for Treatments 1-7 were re-analysed excluding these data. Data were re-analysed by analysis of variance and then mean comparisons 1 to 5 above were performed on the smaller data set.

PGFM data were analysed by analysis of variance and then patterns of PGFM concentrations in the plasma over the sampling periods for the different treatment groups were compared using tests of homogeneity of regression over the sampling period. The following orthogonal set of comparisons was made among the 11 treatment groups: (1) Treatment 1 compared with Treatment 2; (2) Treatments 1 and 2 compared with Treatment 3; (3) Treatments 1, 2 and 3 compared with Treatment 4; (4) Treatments 1,2,3 and 4 compared with Treatment 5; (5) Treatments 1, 2, 3, 4 and 5 compared with Treatment 6 (the above comparisons were performed because it was anticipated that no response to oxytocin challenge had occurred); (6) Treatments 1, 2, 3, 4, 5 and 6 compared with Treatment 7; (7) Treatment 9 compared with Treatment 11 ('follicular-wave' oestradiol with or without concurrent progesterone); (8) Treatments 9 and 11 compared with Treatment 8 (effect of 'follicular-wave' oestradiol); (9) Treatments 8, 9 and 11 compared with Treatment 10 (effect of progesterone withdrawal); (10) Treatments 1, 2, 3, 4, 5, 6 and 7 compared with Treatments 8 , 9,10 and 11 .

\section{Results}

Mean $K_{\mathrm{A}}, R_{\mathrm{o}}$ and $R_{10}$ values for the 11 treatment groups are presented in Table 2. No differences were detected among mean $K_{\mathrm{A}}$ for the 11 treatment groups. The overall mean $K_{\mathrm{A}}$ was $0.2861 \times 10^{9} \mathrm{M}^{-1}$, corresponding to a $K_{\mathrm{D}}$ of $3.5 \times 10^{-9} \mathrm{M}$, a result which agrees well with our data from cyclic ewes. Results were similar whether $R_{\mathrm{o}}$ or $R_{10}$ was used as a measure of oxytocin binding. When the full data set was analysed the following results were obtained: (1) $R_{\mathrm{o}}$ and $R_{10}$ which were obtained from ewes in Treatments 2 and 3 were not different but were less $(P<0.01)$ than those obtained from ewes in Treatment 1 ; $(2)$ there were no detectable differences among Treatments 4, 5, 6 and 7; (3) no differences were detected among Treatments 8, 9, 10 and $11 ;(4)$ both $R_{\mathrm{o}}$ and $R_{10}$ were less $(P<0.01)$ in ewes treated with 5 days of progesterone compared with ewes treated with 12 days of progesterone (Treatments 4 and 5 combined versus Treatments 8 and 9); (5) oestradiol administration had no detectable effect after 5 or 12 days of progesterone and there was no interaction between number of days of progesterone treatment and oestradiol treatment. There was greater variance among the $R_{\mathrm{o}}$ and $R_{10}$ values for Treatments 8-11 compared with Treatments 1-7. We therefore re-analysed the $R_{0}$ and $R_{10}$ data excluding values for Treatments $8-11$. As in the analysis using the full data set, no difference occurred between the means from Treatments 2 and 3 , and the two treatments combined were less than the mean for Treatment 1 . Also, $R_{\mathrm{o}}$ and $R_{10}$ were less $(P<0.05)$ for Treatments 4 and 5 combined compared with Treatments 6 and 7 combined, indicating that progestagen pre-treatment decreased oxy tocin receptor numbers for ewes treated with progesterone for 5 days and ewes treated with progesterone for 5 days plus oestradiol on Days 4 and 5 . Oestradiol administration on Days 4 and 5 of progesterone treatment increased both $R_{\mathrm{o}}$ and $R_{10}$ $(P<0.01)$ compared with progesterone treatment alone (Treatments 4 and 6 versus Treatments 5 and 
Table 2. Oxytocin receptor affinity $\left(K_{\mathrm{A}}, \times 10^{9} \mathrm{M}^{-1}\right)$, and concentration of binding sites from Scatchard analysis $\left(R_{0}\right.$, $\mathrm{fmol} / \mathrm{mg}$ membrane protein) and oxytocin binding at $10 \mathrm{nM}$ oxytocin $\left(R_{10}, \mathrm{fmol} / \mathrm{mg}\right.$ membrane protein) for ewes in each treatment group (Table 1)

\begin{tabular}{lrrr}
\hline Treatment & $K_{\mathrm{A}}{ }^{\ddagger}$ & $R_{\mathbf{0}} \dagger \ddagger$ & $R_{\mathbf{1 0}}{ }^{\dagger \ddagger}$ \\
\hline (1) CO & $0 \cdot 21$ & 1802 & 1123 \\
(2) $\mathrm{E}+\mathrm{CO}$ & $0 \cdot 41$ & 394 & 279 \\
(3) PP + E + CO & $0 \cdot 36$ & 398 & 291 \\
(4) PP + E + 5P & $-*$ & 56 & 39 \\
(5) PP + E + 5P + 4,5E & $0 \cdot 25$ & 293 & 207 \\
(6) $\mathrm{NP}+\mathrm{E}+5 \mathrm{P}$ & $-*$ & 128 & 106 \\
(7) $\mathrm{NP}+\mathrm{E}+5 \mathrm{P}+4,5 \mathrm{E}$ & $0 \cdot 22$ & 758 & 481 \\
(8) PP + E + 12P & $0 \cdot 24$ & 1700 & 1053 \\
(9) PP + E + 12P + 11,12E & $0 \cdot 22$ & 2405 & 1446 \\
(10) PP + E + 10P + 11,12NT & $0 \cdot 29$ & 2177 & 1420 \\
(11) PP + E + 10P + 11,12E & $0 \cdot 37$ & 2262 & 1731 \\
\hline
\end{tabular}

*Scatchard plots could not be done for all ewes due to low binding and so receptor affinity is not reported. In these ewes, $R_{10}$ was used as the estimate of $R_{0}$.

† Standard error of means from analysis of variance of all 11 treatment groups for $K_{\mathrm{A}}, R_{0}$ and $R_{10}$ were $0 \cdot 11,287 \cdot 8$ and $126 \cdot 7$, respectively.

\$Standard error of means from analysis of variance of first 7 treatment groups for $R_{0}$ and $R_{10}$ were 185.9 and $81 \cdot 3$, respectively.

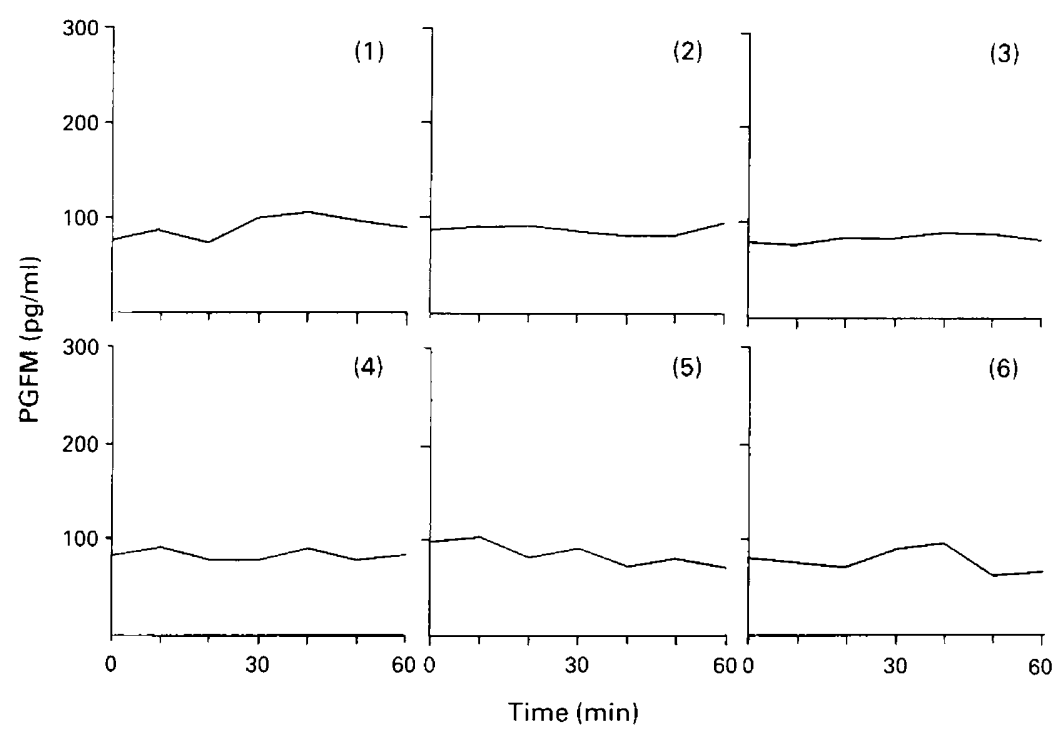

Fig. 1. Mean concentrations of PGFM in plasma of ewes from treatment groups which did not result in a PGFM increase in response to a $1 \mu \mathrm{g}$ intravenous oxytocin challenge. Treatments were (1) $\mathrm{CO}$; (2) $\mathrm{E}+\mathrm{CO}$; (3) $\mathrm{PP}+\mathrm{E}+\mathrm{CO}$; (4) $\mathrm{PP}+\mathrm{E}+5 \mathrm{P}$; (5) $\mathrm{PP}+\mathrm{E}+5 \mathrm{P}+4,5 \mathrm{E}$ and (6) NP $+E+5 P$ (see Table 1 for details of each treatment). Standard error of means of PGFM concentrations from analysis of variance was $13.3 \mathrm{pg} / \mathrm{ml}$. 

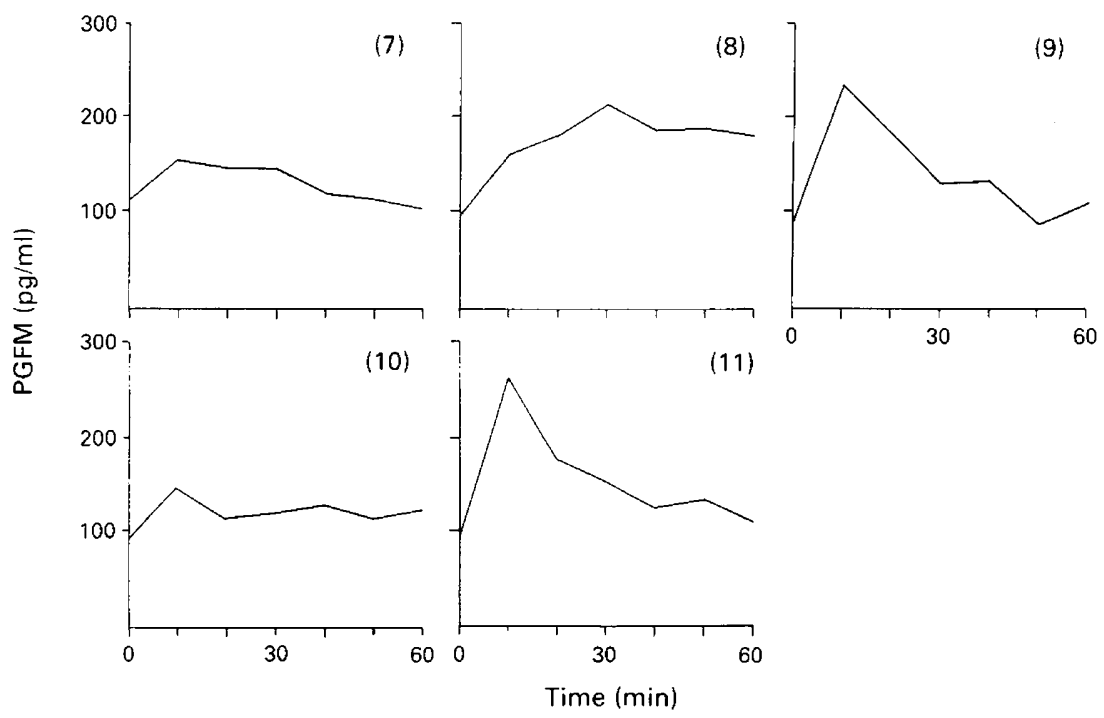

Fig. 2. Mean concentrations of PGFM in plasma of ewes from treatment groups which did result in a PGFM increase in response to a $1 \mu \mathrm{g}$ intravenous oxytocin challenge. Treatments were (7) $\mathrm{NP}+\mathrm{E}+5 \mathrm{P}+$ 4,5E; (8) $\mathrm{PP}+\mathrm{E}+12 \mathrm{P}$; (9) $\mathrm{PP}+\mathrm{E}+12 \mathrm{P}+11,12 \mathrm{E}$; (10) PP + $\mathrm{E}+10 \mathrm{P}+11,12 \mathrm{NT}$ and (11) PP $+\mathrm{E}+10 \mathrm{P}+11,12 \mathrm{E}$ (see Table 1 for details of each treatment). Standard error of means of PGFM concentrations from analysis of variance was $13 \cdot 3 \mathrm{pg} / \mathrm{ml}$.

7). No interaction was detected between progestagen pre-treatment and 'follicular-wave' oestradiol administration.

Mean PGFM concentrations from each treatment over the 1-h sampling period are illustrated in Figs 1 and 2. There were no statistically significant differences among the treatment groups in PGFM concentrations before oxytocin treatment. Tests for homogeneity of regression over the sampling period indicated that PGFM patterns for Treatments 1-6 were not different from each other but were different $(P<0.05)$ from the pattern for Treatment 7 . Examination of the data indicates that Treatments $1-6$ did not result in a PGFM response to oxytocin, while Treatment 7 did result in a PGFM response to oxytocin. The PGFM pattern in the plasma over the sampling period was not different for Treatments 9 and 11 but the two combined were different $(P<0.01)$ from Treatment 8. Examination of the patterns of PGFM in plasma after oxytocin administration indicates that mean peak values of PGFM in response to oxytocin were not different. Instead, 'follicular-wave' oestradiol administration either with or without concurrent progesterone administration appeared to cause PGFM to increase more rapidly (within $10 \mathrm{~min}$ ) and then decay more rapidly compared to that with progesterone administration alone (peak at $30 \mathrm{~min}$ ). The pattern of PGFM in plasma for Treatments 8,9 and 11 combined was different from that for Treatment 10 $(P<0.05)$.

\section{Discussion}

The results of this experiment provide the basis for a hypothesis for the control of oxytocin-induced PGFM concentrations in the ewe, and therefore for the control of luteolysis. The results identify several characteristics of steroid control both of oxytocin receptor and uterine response to oxytocin which have not been reported previously.

First, oestradiol alone had a long-term (i.e. at least 5 days) inhibitory effect on oxytocin receptors in endometrium (Treatment 2 versus Treatment 1) and progestagen pre-treatment did not 
cause further inhibition (Treatment 2 versus Treatment 3). Second, endometrium from corn oiltreated ewes has a relatively high level of oxytocin receptor which is uncoupled from PGF synthesis. This occurred even though the uteri of corn oil-treated ewes appeared small and unstimulated, suggesting that basal concentrations of steroid hormones were not adequate to cause stimulation of the tissue. Third, progestagen pre-treatment has a long-term (i.e. at least 7 days) enhancing effect on inhibition of oxytocin receptors by subsequent progesterone treatment. This effect is most apparent in ewes which are subsequently treated with both progesterone and oestradiol, since lack of progestagen pre-treatment combined with progesterone treatment for 5 days and oestradiol treatment on Days 4 and 5 of progesterone treatment resulted in both increased oxytocin receptor numbers and, more importantly, an increase in PGFM in response to oxytocin. Fourth, this experiment indicates that progesterone alone is capable eventually (i.e. after 12 days) of inducing endometrial oxytocin receptor concentrations and oxytocin-induced increases in PGFM. Administration of 'follicular-wave' oestradiol, progesterone withdrawal or the two combined (Treatments 9, 10 and 11 , respectively) caused no further increase in oxytocin receptor concentrations compared with progesterone treatment alone (Treatment 8). However, oestradiol changed the pattern of PGF release after long-term progesterone treatment. In contrast to oestradiol treatment on Days 11 and 12 of progesterone treatment, oestradiol did increase oxytocin receptors if administered on Days 4 and 5 of progesterone administration.

The first conclusion above indicates that the oestradiol which occurs coincident with oestrus in cyclic ewes may contribute to the subsequent decrease in oxytocin receptor concentrations which occurs during the next cycle (Treatments 2 and 3 combined versus Treatment 1). The fact that within the same experiment 'follicular-wave' oestradiol was found to increase oxytocin receptor concentration (Treatments 4 and 6 combined versus Treatments 5 and 7) suggests that the effect of oestradiol on oxytocin receptor may be biphasic, being initially stimulatory ( $1-2$ days) and then inhibitory (5-7 days).

The high oxytocin receptor concentrations in endometrium from corn oil-treated ewes occur in the absence of PGFM release in response to oxytocin. It is possible that the high levels of receptor in this tissue could be caused by the loss of extraneous tissue from endometrium (i.e. loss of cells which do not contain receptor, thereby concentrating those cells which do). However, this finding suggests that endometrial oxytocin receptor concentrations expressed per mg tissue protein do not always reflect endometrial responsiveness to oxytocin and that, with oxytocin binding, other factors within PGF-producing cells are important in controlling PGF release. The observation that both removal of progesterone and administration of oestradiol can alter PGF release in response to oxytocin without altering oxytocin receptor concentrations suggests that these hormones control factors which are involved in the coupling of oxytocin receptor to PGF synthesis. It has been suggested that the effects of oxytocin in endometrium are mediated by phosphatidylinositol turnover as a second messenger system (Flint et al., 1986). Several factors are involved in this system. These include $\mathrm{G}$ proteins, hormone-sensitive phospholipase C, precursor phospholipids (e.g. polyphosphatidylinositols) in hormone-sensitive lipid stores, concentrations and availability of inositol triphosphate receptors, intracellular calcium concentrations and others (Berridge, 1987). Each could be influenced by both progesterone and/or oestradiol. Dissociation of the oxytocin receptor from PGF synthesis has been observed previously in ovariectomized, steroid-treated ewes which were refractory to oxytocin after an oxytocin challenge, even though oxytocin receptor concentrations were unaffected (Sheldrick \& Flint, 1986). Finally, the observation that corn oil-treated ewes have high receptors requires confirmation as well as a more extensive characterization of the receptors, to confirm that they are authentic oxytocin receptors.

It has been suggested that oxytocin receptor which is uncoupled to PGF release may be crossreacting vasopressin receptors. There are several reasons why this is unlikely. First, Sheldrick \& Flint (1985) and Ayad \& Wathes (1989) reported a single binding site for oxytocin in the range of oxytocin used in this experiment by virtue of a straight Scatchard plot; if receptors for both oxytocin and vasopressin are present in endometrium a curvilinear Scatchard plot should result. 
Secondly, the oxytocin receptor itself binds vasopressin with higher (Sheldrick \& Flint, 1985) or equal (Ayad \& Wathes, 1989) affinity, again suggesting that there are not separate vasopressin and oxytocin receptors which bind oxytocin within nanomolar oxytocin concentration ranges used in this experiment. Finally, true vasopressin receptors might be expected to be present regardless of steroid treatment, yet progesterone treatment for 5 days inhibited nearly all receptors in our assay, again suggesting that the receptors measured in this experiment were oxytocin receptors.

The observation that lack of progestagen pre-treatment decreases the subsequent inhibitory effect of progesterone on endometrial oxytocin receptors provides an explanation for the results of McLeod et al. (1982) and Southee et al. (1988a), which indicated that ewes induced to cycle during anoestrus by GnRH treatment sometimes undergo short cycles (6-7 days) unless given progesterone pre-treatment. Hunter et al. (1989) reported that unprimed GnRH-treated ewes had more oxytocin receptors and more PGF episodes which were coincident with oxytocin release. Our results therefore provide an explanation for these observations. More importantly, the results from this experiment indicated that 'follicular-wave' oestradiol treatment caused an increase in oxytocininduced PGF release in unprimed ewes but not in primed ewes. It has been reported that a peak in oestrogen occurs around Day 3 of the cycle (Smith et al., 1976). Therefore, unprimed ewes may be more sensitive to oestrogen during the early luteal phase and the first peak in oestradiol concentrations during the cycle may induce premature luteolysis.

The observation that oestradiol causes a more rapid PGF release in response to oxytocin may partly explain the high-amplitude peaks of PGF which occur on Days 15 and 16 of the oestrous cycle. Progesterone concentrations decrease and oestrogen concentrations increase at this time, providing a steroid pattern similar to that administered to ewes in Treatment 11. It may be that this combination of steroids helps to generate high-amplitude, short-duration spikes of PGF in response to endogenous oxytocin, a pattern of PGF administration which has been reported to be most effective in causing luteolysis (Schramm et al., 1983). Karsch et al. (1970) found that irradiation of follicles and, therefore, removal of follicular oestrogen delayed luteolysis in ewes, but did not block luteolysis entirely. Instead, luteolysis occurred over a greater time period, suggesting that the effect of oestradiol is to decrease the time required for luteolysis to occur. Our results suggest that oestrogen may modify the mode of PGF release.

An additional effect of oestradiol is suggested by comparing oxytocin-induced PGFM concentrations from Treatment 8 (progesterone maintained), Treatment 10 (progesterone withdrawn) and Treatment 11 (progesterone withdrawn plus oestradiol treatment). Progesterone withdrawal (Treatment 10) decreased oxytocin-induced PGFM concentrations compared to maintenance of progesterone (Treatment 8). Oestradiol treatment (Treatment 11) maintained oxytocin-induced PGFM concentrations. This suggests that a further effect of oestradiol is to maintain the luteolytic mechanism after progesterone falls in response to PGF, so that luteolysis proceeds to completion.

McCracken et al. (1984) proposed an hypothesis for steroid control of the oxytocin receptor in the endometrium of the ewe, i.e. that progesterone inhibits the endometrial response to oestrogen by inhibiting oestradiol receptors during the mid-luteal phase. Our data are consistent with this hypothesis and we can add the observation that progestagen pre-treatment enhances the effect of subsequent progesterone. McCracken et al. (1984) also suggested that, at the end of the cycle, the inhibitory effect of progesterone is lost, possibly by down-regulation of progesterone receptors by progesterone. The endometrium is then sensitive to oestrogen and oestrogen induces luteolysis. The results of the present experiment are not consistent with several aspects of this part of their hypothesis. First, progesterone alone was able to induce oxytocin receptor concentrations and increase uterine response to oxytocin, while oestradiol gave no further increase. Second, if the increase in oxytocin receptor concentrations and uterine responsiveness were caused by a decrease in progesterone receptors, no difference should occur between ewes treated with progesterone for 12 days and ewes given progesterone for 10 days and no treatment on Days 11 and 12. Both groups would be undergoing progesterone withdrawal. Our results indicate that, while oxytocin receptor 
concentrations were not different between these two treatment groups, uterine response to oxytocin was decreased in ewes for which progesterone was withdrawn. This suggests that the luteolytic mechanism requires progesterone, and therefore must also require progesterone receptors.

Finally, our measurements of receptor affinity using Scatchard analysis at 3 concentrations of oxytocin suggest that the changes observed in binding of oxytocin are probably due to changes in receptor concentrations and not affinity. While it is true that the methods employed in this study to determine receptor affinity are not as accurate as they would be if more extensive characterization of the affinity was performed, they are accurate enough to suggest that it is changes in receptor concentrations which are responsible for the changes in oxytocin binding observed in this experiment. Changes in receptor affinity would have to be quite large to result in the large changes we observed in oxytocin binding. There may be slight changes in receptor affinity among the different treatment groups which we would have failed to detect using our method and so we cannot conclude that no receptor affinity changes occurred, only that the changes in oxytocin binding were not primarily due to changes in receptor affinity. Caution should be used in applying any other interpretation to these data.

The results from this experiment suggest a model for control of endometrial oxytocin receptor, uterine PGF release and therefore oestrous cycle duration in ewes. The normal response of endometrium to progesterone and oestrogen requires prior exposure to progesterone. The first cycle which occurs after anoestrus may be shortened due to the lack of progesterone pre-treatment, but probably provides progesterone priming for the subsequent cycle. In cyclic ewes, both long-term effects of oestradiol and short-term effects of progesterone may synergize to decrease oxytocin receptors and inhibit the luteolytic mechanism. Oestradiol can increase oxytocin receptors during midcycle but long-term progesterone treatment alone is sufficient to induce both oxytocin receptors and PGF release in response to oxytocin. Oestrogen, while not absolutely essential for stimulating oxytocin receptor concentrations and oxytocin-induced PGF release from the endometrium, may modify the time course of PGF release in response to oxytocin, which may enhance the effectiveness of each PGF episode. Also, oestrogen may maintain the luteolytic mechanism when progesterone concentrations fall in response to PGF. This hypothesis places the effects of progesterone on endometrial oxytocin receptor in a dominant role for control of luteolysis and differs from that of McCracken (1980) in the role played by oestrogen. These results suggest that timing of luteolysis depends on the temporal pattern of endometrial response to progesterone, instead of the temporal pattern of changes in progesterone and oestrogen. Lastly, these data indicate that PGF release is not solely controlled by endometrial oxytocin receptors, and suggest that both progesterone and oestradiol may affect other steps in the process of PGF release in response to oxytocin binding.

We thank Mr D. Smith, Mr R. Walker and Mr M. Baker for help with the surgical work; $\mathrm{Mr}$ Nick Skinner and Miss Christine Myles for technical support; and Professor A. P. F. Flint for valuable criticism of the manuscript.

\section{References}

Ayad, V.J. \& Wathes, D.C. (1989) Characterisation of endometrial and myometrial oxytocin receptors in the non-pregnant ewe. $J$. Endocr. 123, 11-18.

Berridge, M.J. (1987) Inositol triphosphate and diacylglycerol: two interacting second messengers. Ann. Rev. Biochem. 56, 159-193.

Flint, A.P.F. \& Sheldrick, E.L. (1983) Evidence for a systemic role for ovarian oxytocin in luteal regression in sheep. J. Reprod. Fert. 67, 215-225.

Flint, A.P.F., Leat, W.M.F., Sheldrick, E.L. \& Stewart, H.S. (1986) Stimulation of phosphoinositide hydroly- sis by oxytocin and the mechanism by which oxytocin controls prostaglandin synthesis in the ovine endometrium. Biochem. J. 237, 797-805.

Ford, S.P., Weems, C.W., Pitts, R.E., Pexton, J.E., Butcher, R.L. \& Inskeep, E.K. (1975) Effects of oestradiol-17 $\beta$ and progesterone on prostaglandin $F$ in sheep uteri and uterine venous plasma. J. Anim. Sci. 41, 1407-1413.

Goding, J.R. (1974) The demonstration that PGF-2 $\alpha$ is the uterine luteolysin in the ewe. J. Reprod. Fert. 38, $261-271$. 
Homanics, G.E. \& Silvia, W.J. (1988) Effects of progesterone and estradiol-17 $\beta$ on uterine secretion of prostaglandin F-2 $\alpha$ in response to oxytocin in ovariectomized ewes. Biol. Reprod. 38, 804-811.

Hooper, S.B., Watkins, W.B. \& Thorburn, G.D. (1987) Oxytocin, oxytocin-associated neurophysin, and prostaglandin $F-2 \alpha$ concentrations in the uteroovarian vein of pregnant and non-pregnant sheep. Endocrinology 119, 2590-2597.

Hunter, M.G., Ayad, V.J., Gilbert, C.L., Southee, J.A. \& Wathes, D.C. (1989) Role of prostaglandin F-2 $\alpha$ and oxytocin in the regression of $\mathrm{GnRH}$-induced abnormal corpora lutea in anoestrus ewes. $J$. Reprod. Fert. 85, $551-561$.

Kaker, M.L., Murrey, R.D. \& Dobson, H. (1984) Plasma hormone changes in cows during induced or spontaneous calving and the early post partum period. Vet. Rec. 115, 378-382.

Karsch, F.J., Noversoske, J.W., Roche, J.F., Norton, H.W. \& Nalbandov, A.V. (1970) Maintenance of ovine corpora lutea in the absence of ovarian follicles. Endocrinology 87, 1228-1236.

Louis, T.M., Parry, D.M., Robinson, J.S., Thorburn, G.D. \& Challis, J.R.G. (1977) Effects of exogenous progesterone and oestradiol on prostaglandin $F$ and 13,14-dihydro-15-oxo prostaglandin F-2 $\alpha$ concentrations in uteri and plasma of ovariectomized ewes. $J$. Endocr. 73, 427-439.

Lowry, O.H., Rosebrough, N.J., Farr, A.L. \& Randall, R.J. (1951) Protein measurement with the Folin phenol reagent. J. biol. Chem. 193, 265-275.

McCracken, J. (1980) Hormone receptor control of prostaglandin F-2 $\alpha$ secretion by the ovine uterus. Adv. Prost. Thromb. Res. 8, 1329-1344.

McCracken, J.A., Schramm, W. \& Okulicz, W.C. (1984) Hormone receptor control of pulsatile secretion of $\mathrm{PGF}_{2 a}$ from the ovine uterus during luteolysis and its abrogation in early pregnancy. Anim. Reprod. Sci. 7, $31-55$.

McLeod, B.J., Haresign, W. \& Lamming, G.E. (1982) Response of seasonally anoestrous ewes to small-dose multiple injections of $\mathrm{GnRH}$ with and without progesterone pre-treatment. J. Reprod. Fert. 65, 223-230.

Miller, B.G., Moore, N.W., Murphy, L. \& Stone, G.M. (1977) Early pregnancy in the ewe: effects of oestra- diol and progesterone on uterine metabolism and on embryo survival. Aust. J. biol. Sci. 30, 279-288.

Roberts, J.S., Barcikowski, B., Wilson, L., Skarnes, R.C. \& McCracken, J.A. (1975) Hormonal and related factors affecting the release of prostaglandin F-2 $\alpha$ from the uterus. J. Steroid Biochem. 6, 1091-1097.

Roberts, J.S., McCracken, J.A., Gavagan, J.E. \& Solofi, M.S. (1976) Oxytocin-stimulated release of prostaglandin F-2 $\alpha$ from ovine endometrium in vitro: correlation with oestrous cycle and oxytocin-receptor binding. Endocrinology 99, 1107-1114.

Scaramuzzi, R.J., Baird, D.T., Boyle, H.P, Land, R.B. \& Wheeler, A.G. (1977) The secretion of prostaglandin F from the autotransplanted uterus of the ewe. $J$. Reprod. Fert. 49, 157-160.

Sheldrick, E.L. \& Flint, A.P.F. (1985) Endocrine control of uterine oxytocin receptors in the ewe. $J$. Endocr. 196, 249-258.

Sheldrick, E.L. \& Flint, A.P.F. (1986) Transient uterine refractoriness after oxytocin administration in ewes. J. Reprod. Fert. 77, 523-529.

Sheldrick, E.L., Mitchell, M.D. \& Flint, A.P.F. (1980) Delayed luteal regression in ewes immunized against oxytocin. J. Reprod. Fert. 59. 37-42.

Schramm, W., Bovaird, L., Glew, M.E., Schramm, G. \& McCracken, J.A. (1983) Corpus luteum regression induced by ultra-low pulses of prostaglandin F-2 $\alpha$. Prostaglandins 26, 347-364.

Smith, J.F., Drost, H., Fairclough, R.J., Peterson, A.J. \& Tervit, H.R. (1976) Effect of age on peripheral levels of progesterone and oestradiol-17ß, and duration of oestrus in Romney Marsh ewes. N.Z. Jl agric. Res. 19, 277-280.

Southee, J.A., Hunter, M.G. \& Haresign, W. (1988a) Function of abnormal corpora lutea in vivo after GnRH-induced ovulation in the anoestrous ewe. $J$. Reprod. Fert. 84, 131-137.

Southee, J.A., Hunter, M.G., Law, A.S. \& Haresign, W. (1988b) Effect of hysterectomy on the short life-cycle corpus luteum produced after $\mathrm{Gn}-\mathrm{RH}$-induced ovulation in the anoestrous ewe. J. Reprod. Fert. 84, 149-155.

Received 4 May 1990 